\title{
Questes
}

\section{Entresims : quand la poésie pousse en branches}

\section{Agathe Sultan}

\section{(2) OpenEdition}

\section{Journals}

\section{Édition électronique}

URL : http://journals.openedition.org/questes/1756

DOI : 10.4000/questes. 1756

ISSN : 2109-9472

\section{Éditeur}

Les Amis de Questes

\section{Édition imprimée}

Date de publication : 15 mai 2003

Pagination : 16-20

ISSN : 2102-7188

\section{Référence électronique}

Agathe Sultan, «Entresims : quand la poésie pousse en branches », Questes [En ligne], 4 | 2003, mis en ligne le 01 janvier 2014, consulté le 15 septembre 2020. URL : http://journals.openedition.org/ questes/1756

Ce document a été généré automatiquement le 15 septembre 2020.

(c) Association des amis de «Questes» 


\title{
Entresims : quand la poésie pousse en branches
}

\author{
Agathe Sultan
}

NOTE DE L'ÉDITEUR

Cet article n'a pas encore fait l'objet d'une autorisation de publication.

INDEX

Mots-clés : arbre, poète, troubadours, printemps

Keywords : tree, poet, troubadours, spring 